\title{
Testiranje primjenjivosti Altmanovog Z-score modela za predviđanje stečaja u Republici Hrvatskoj
}

\section{Testing the applicability of the Altman's Z-score model for predicting bankruptcy in the Republic of Croatia}

\section{Sažetak}

Altmanov Z-score jedan je od najpoznatijih modela za predviđanje poslovnih poteškoća odnosno stečaja. Cilj ovog rada je testirati Altmanov Z-score model i utvrditi u kojoj je mjeri primjenjiv u predviđanju stečaja u Republici Hrvatskoj. Testirani ukupni uzorak sa Zagrebačke burze sastojao se od 52 poslovna subjekta, od čega 26 koji su otvorili stečaj i 26 sa stabilnim poslovanjem, te je isti promatran u ukupnom vremenskom razdoblju 2007.-2016. Budući da se testirani uzorak sastojao i od poslovnih subjekata koji ne pripadaju proizvodnom sektoru, u istraživanju je korišten Altmanov revidirani Z"-score model. Osim testiranja uspješnosti istog, u radu su se nastojali prilagoditi ponderi Z"-score modela primjenom višestruke diskriminantne analize u cilju dobivanja modela koji će biti prilagođeniji hrvatskom tržištu. Radi prisutnosti multikolinearnosti nisu sve varijable zadržane u modelu, te je dobiven model koji ima slabiju uspješnosti od Z"-score modela. Rezultati ovog istraživanja ukazuju da je Altmanov Z"-score primjenjiv na hrvatskom tržištu, ali se preporuča koristiti ga kao dodatni, a nikako kao osnovni pokazatelj za predviđanje stečaja.

Ključne riječi: financijska analiza, poslovni neuspjeh, bankrot, stabilno poslovanje, financijski pokazatelji JEL klasifikacija: G32; G33

\section{Abstract}

Altman's Z-score model is one of the well-known financial ratios whose purpose is reflected in the possibility of predicting bankruptcy for businesses. The aim of this paper was to test Altman's Z-score model in order to determine whether the model is applicable in the bankruptcy forecasting on the example of Croatian companies. The analysed and tested sample from the Zagreb Stock Exchange was consisted of 52 companies which were divided into two samples: 26 companies which were financially stable and 26 companies that went bankrupt. Sample was observed over the time period 2007-2016 and it was consisted of businesses that do not belong only to the manufacturing sector, therefore it was used Altman's revised Z"- score model. Beside analysing its performance, authors in this paper tried to adjust the weights of the Z"-score model by applying multiple discriminant analysis in order to obtain a model that would be more tailored to the Croatian market. Due to the presence of multicollinearity, not all variables could be retained, and a model with lower performance was obtained. The results of this research indicates that Altman's Z"-score is applicable in the Croatian market, but it is recommended to use it only as an additional, not basic indicator for predicting bankruptcy.

Keywords: financial analysis, business failure, bankruptcy, financial stability, financial indicators JEL classification: G32; G33
Doc.dr.sc.Siniša Bogdan

Fakultet za menadžment u turizmu i ugostiteljstvu Sveučilišta u Rijeci E-mail: sinisab@fthm.hr

\section{Doc. dr.sc. Suzana Bareša}

Fakultet za menadžment u turizmu i ugostiteljstvu Sveučilišta u Rijeci E-mail:suzanab@fthm.hr

Velimir Hađina, mag. oec. Fakultet za menadžment u turizmu i ugostiteljstvu Sveučilišta u Rijeci E-mail:velimir.hadina@gmail.com

Asst. prof.Siniša Bogdan, PhD Faculty of Tourism and Hospitality Management, University of Rijeka E-mail: sinisab@fthm.hr

\section{Asst. prof.Suzana Bareša, PhD} Faculty of Tourism and Hospitality Management, University of Rijeka E-mail: suzanab@fthm.hr

\section{Velimir Hađina, MSc}

Faculty of Tourism and Hospitality Management, University of Rijeka E-mail:velimir.hadina@gmail.com 
Bogdan, S., Bareša, S., Hađina,V.

Testiranje primjenjivosti Altmanovog Z-score modela za predviđanje stečaja u Republici Hrvatskoj

\section{Uvod}

Predviđanje poslovnih poteškoća i stečaja poslovnih subjekata u znanstvenim krugovima, poslovnom svijetu, te u javnosti općenito, posljednjih 50-ak godina pobuđuje sve veći interes i pozornost. Mogu li se i kako unaprijed uočiti nadolazeće financijske teškoće, može li se sa sigurnošću predvidjeti stečaj poslovnog subjekta kao događaj u budućnosti? Takva i slična pitanja otvarala su istraživačke horizonte i poticala razne znanstvene rasprave i istraživanja na ovu temu. Značajniji korak u istraživanju ove problematike postigao je Altman (1968.) koji je u traženju odgovora o mogućnosti predviđanja nadolazećih poslovnih poteškoća ponudio model Z-score, što je pobudilo interes velikog broja znanstvenika koji su nastojali razviti što uspješniji model koji omogućava testiranje vjerojatnosti nastanka stečaja poslovnog subjekta. U modelima za predviđanje stečaja istraživači su nastojali implementirati niz statističkih i matematičkih metoda i uključiti one varijable koje su smatrali signifikantnim za predviđanje stečaja, odnosno čijom bi se kombinacijom postiglo što preciznije predviđanje. „Mnoge su studije bile posvećene potrazi za najboljim modelom korporativnog predviđanja koji se temelji na javno dostupnim podacima i statističkim tehnikama“ (0oghe i sur., 2009:7).

Originalni Altmanov Z-score model (1968.) stvoren za potrebe američkog tržišta prvotno je bio namijenjen poslovnim subjektima koji kotiraju na burzi, te se nalaze unutar sektora proizvodnje. Kasnijim revidiranjem originalnog modela konstruiran je Z'-score model (1983.) namijenjen poslovnim subjektima koji ne kotiraju na burzi, te Z"-score model (1983.) koji je namijenjen analizi poslovnih subjekata izvan sektora proizvodnje. Budući da da je navedeni model pozitivno prihvaćen od strane akademske zajednice, a i privatnog sektora cilj ovog istraživanja, za razliku od dosadašnjih istraživanja bio je testirati uspješnost Altmanovog Z"-score modela koji je prilagođen poslovnim subjektima koji nisu nužno unutar proizvodnog sektora. Osim navedenog cilja, u radu će se nastojati korištenjem originalne metodologije (višestruke diskriminantne analize) prilagoditi pondere Z"-score modela (zadržavajući pritom iste varijable) kako bi se dobio model prilagođeniji hrvatskom tržištu.

Slična istraživanja vezana uz provjeravanje uspješnosti predviđanja Altmanovim modelom provedena su na primjeru poslovnih subjekata u Jordanu (Alareeni i Branson, 2013.), Pakistanu (Hussain i sur., 2014.), Italiji (Celli, 2015.), te su potaknula autore u ovome radu da također odgovore na pitanje može li se Altmanov Z-score model primijeniti kao instrument za predviđanje stečaja i u kojoj mjeri se može ocijeniti njegova pouzdanost. Aktualnost i relevantnost navedene problematike proizlazi i iz trenutno loše situacije unutar privatnog sektora Republike Hrvatske. Naime, prema posljednjim podacima hrvatske financijske agencije (FINA, 2019.) od srpnja 2019. godine, ukupan iznos neizvršenih osnova za plaćanje poslovnih subjekata u Hrvatskoj iznosio je gotovo 6,2 milijarde kuna, što upućuje na visok iznos sredstava temeljem kojega su otvoreni ili će u budućnosti biti otvoreni novi stečajevi.

U životnom ciklusu poslovnog subjekta izmjenjuju se pozitivna (uspješna) i negativna (neuspješna) razdoblja, međutim „kad se negativno razdoblje prebaci s privremenog na strukturno i kronično (i tako se nastavlja s vremenom), tvrtka je često osuđena bankrotirati“ (Altman i sur., 2013.) Stvaranje modela koji bi mogao pravodobno signalizirati financijske poteškoće i predvidjeti vjerojatnost stečaja poslovnog subjekta od velike je važnosti za detekciju problema, kao i za otvaranje mogućnosti pravodobnog poduzimanja mjera i aktivnosti kako bi se smanjile i/ili spriječile njegove posljedice.

Rad je, uz uvod i zaključak, podijeljen u tri glavna poglavlja. U drugom poglavlju rada dan je pregled najvažnijih dosadašnjih istraživanja na temu predviđanja stečaja poslovnih subjekata, posebice onih u Hrvatskoj, te su definirani svi postojeći oblici Altmanovog pokazatelja. U trećem poglavlju objašnjena je i prikazana metodologija provođenja istraživanja, te su definirani podaci temeljem kojih je provedeno istraživanje. Shodno cilju istraživanja, nakon ispitivanja primjenjivosti i ispravnosti predviđanja stečaja primjenom Altmanovog Z"score modela na primjeru poslovnih subjekata u Hrvatskoj, u četvrtom dijelu su iznijeti rezultati i nalazi istraživanja, jednako kao i rezultati dobiveni temeljem višestruke diskriminantne analize nakon 
prilagodbe pondera na Z"-score modelu u cilju dobivanja prilagođenijeg modela za hrvatsko tržište. U završnom dijelu slijede sintetizirani stavovi autora 0 primjenjivosti Altmanove metodologije na primjeru hrvatskih poslovnih subjekata, uz navođenje ograničenja istraživanja i preporuke za buduća istraživanja.

\section{Dosadašnja istraživanja}

Problematika predviđanja poslovnog neuspjeha i traženje modela koji sa što većom vjerojatnošću predviđa financijske poteškoće poslovnih subjekata razvija se od kasnih 60-tih godina, te se i danas mnoga istraživanja bave ovom problematikom. Sam razvoj predviđanja stečaja poslovnih subjekata pojavio se na prijelazu iz 19. u 20. stoljeće s korištenim jednim pokazateljem, da bi krajem 60in godina bila objavljena istraživanja koja su tezu mogućnosti predviđanja stečaja opravdavali s nekoliko financijskih pokazatelja.

Početkom 20. stoljeća primijenjeni su prvi ekonometrijski pokazatelji predloženi za opisivanje predviđanja poslovnog neuspjeha što je predstavljalo prve pokušaje formalnog predviđanja stečaja. Tada su razvijeni modeli koji su služili kao pomoć bankama u donošenju odluka hoće li odobriti ili odbiti zahtjeve za kredit (Ramser i Foster, 1931.; Fitzpatrick, 1932.; Winakor i Smith, 1935.; Wall, 1936.).

Prva studija o predviđanju poslovnih teškoća upotrebom financijskih pokazatelja objavljena je 1942. godine od strane Charles L. Merwina, te se smatrala najboljom studijom do 60-tih godina 20.st. odnosno do istraživanja Beavera (1966.). Navedena studija donijela je prekretnicu u istraživanju ranog prepoznavanja simptoma poslovnog neuspjeha i evoluciju modela predviđanja stečaja. Beaver je proučavao stečaj 79 poslovnih subjekata koja su bankrotirala unutar vremenskog razdoblja 1954.-1964., a čiji su financijski izvještaji bili dostupni godinu dana prije bankrota. Navedenih 79 poslovnih subjekata bilo je raspoređeno prema SIC-u (eng. Standard Industrial Classification) u 38 različitih industrijskih grana. Poslovnim subjektima koji su bankrotirali prema industrijskoj grani i veličini, upareni su poslovni subjekti sličnih karakteristika koji imaju stabilno poslovanje kako bi se univarijatnom analizom ispitala prediktivna moć financijskih pokazatelja. Njegov rad smatra se jednim od najznačajnijih radova koji proučava problematiku predviđanja vjerojatnosti financijskih teškoća, odnosno vjerojatnosti poslovnog neuspjeha i stečaja.

Rane studije koje su se odnosile na analizu omjera za predviđanje stečaja bile su univarijatne studije, te su bile usmjerene na pojedinačne omjere i između ostalog uspoređivale su omjere neuspješnih poslovnih subjekata $s$ uspješnim. „Univarijatne studije imale su važne implikacije za razvoj budućih modela s obzirom da su postavile temelje za multivarijatne modele predviđanja stečaja" (Bellovary i sur., 2007:2).

Prvu multivarijatnu studiju objavio je Edward I. Altman (1968.), koji je koristio diskriminantnu analizu kako bi razvio pet-faktorski model za predviđanje stečaja proizvodnih poslovnih subjekata. Model koji je nazvao "Z-score", predviđao je stečaj ukoliko se dobiveni rezultat za analizirani poslovni subjekt nalazio ispod granične vrijednosti koja ukazuje na stečaj. Ovaj model imao je visoku sposobnost predviđanja stečaja. Analizirani uzorak godinu dana prije proglašenja istog imao je 95\%tnu točnost. Međutim, sposobnost ispravnog predviđanja znatno se smanjila s vremenskim pomakom, tako je iznosila $72 \%$ dvije godine prije proglašenja stečaja, $48 \%, 29 \%$ i $36 \%$ točnosti predviđanja za tri, četiri i pet godina prije stečaja. Uzorak na kojemu je Altman temeljio svoje istraživanje sastojao se od 66 poslovnih subjekata u sektoru proizvodnje. Uzorak je bio podijeljen u dvije skupine, odnosno 33 poslovna subjekta koja su bankrotirala i 33 financijski stabilna poslovna subjekta. Poslovni subjekti koji su imali financijske poteškoće, a nisu službeno otvorili stečaj-nisu bili uvršteni u promatrani uzorak. Višestrukom diskriminantnom analizom koja je izabrana kao odgovarajuća statistička tehnika odabrano je pet financijskih pokazatelja koje je Altman smatrao najprikladnijim za predviđanje bankrota, odnosno stečaja poslovnog subjekta, stoga se i originalna rastuća diskriminantna funkcija zapisuje na sljedeći način:

\begin{tabular}{|l|l|}
\hline$Z=1,2 X_{1}+1,4 X_{2}+3,3 X_{3}+0,6 X_{4}+1,0 X_{5}$ & 1 \\
\hline
\end{tabular}

Bogdan, S., Bareša, S., Hađina,V.

Testiranje primjenjivosti Altmanovog Z-score modela za predviđanje stečaja u Republici Hrvatskoj 
Bogdan, S., Bareša, S., Hađina,V.

Testiranje primjenjivosti Altmanovog Z-score modela za predviđanje stečaja u Republici Hrvatskoj
Varijable su definirane na sljedeći način:

$X_{1}$ Obrtni kapital/ukupna imovina

$X_{2}$ Zadržana dobit/ukupna imovina

$X_{3}$ Dobit prije kamata i poreza/ukupna imovina

$X_{4}$ Tržišna vrijednost kompanije knjigovodstvena vrijednost ukupnih obveza

$X_{5}$ Prodaja/ukupna imovina

Granične vrijednosti Z-score modela bile su definirane na način da poslovni subjekti koji ostvaruje Z-score ispod granične vrijednosti 1,81 imaju visoki rizik bankrota dok oni koji ostvaruju koeficijent iznad vrijednosti 2,99 pripadaju skupini „zdravih“ odnosno financijski stabilnih. „Sivoj zoni“ odnosno zoni nesigurnosti pripadaju poslovni subjekti čiji se Z-score nalazi unutar raspona vrijednosti 1,81 i 2,99. Kako se Z-score model pojavljuje u tri forme, osim već prikazanog baznog modela, u nastavku rada biti će predstavljene preostale dvije forme modela.

Budući da se je prethodno navedeni bazni Z-score model mogao primijeniti isključivo na poslovne subjekte koji se nalaze u proizvodnom sektoru, te čije dionice kotiraju na burzi, Edward I. Altman dalje razvija model i prikazuje revidirani Z'-score (Caouette i sur., 2008:148) koji je imao mogućnost primjene na poslovne subjekte koji ne kotiraju na burzi. Navedeni model može se primijeniti na privatne poslovne subjekte budući da je u novom modelu modificirana varijabla X4, odnosno tržišna vrijednost kompanije supstituirana je s knjigovodstvenom vrijednošću kompanije. Budući da su i ponderi izmijenjeni, revidirani model je zaprimio sljedeću formu:

$$
Z^{\prime}=0,717 X_{1}+0,847 X_{2}+3,107 X_{3}+
$$$$
0,420 X_{4}+0,998 X_{5}
$$

Jednako kao i u prethodnom primjeru, postavljene su granične vrijednosti pri čemu poslovni subjekti $s$ izračunatom Z'-score vrijednošću manjom od 1,23 predstavljaju subjekte s visokim rizikom bankrota dok se stabilnim poslovnim subjektima smatraju oni koji imaju izračunati Z'-score viši od 2,90. Ukoliko poslovni subjekt ima Z'-score između navedene dvije vrijednosti tada se smatra da pripada tzv.,sivoj zoni“.

Treći model na osnovi kojeg se izračunava Z"-score namijenjen je privatnim poslovnim subjektima koji se mogu nalaziti i izvan proizvodnog sektora. Navedeni model ima sljedeći oblik:

$$
Z^{\prime \prime}=6,56 X_{1}+3,26 X_{2}+6,72 X_{3}+1,05 X_{4}
$$

Ukoliko je izračunata Z" vrijednost veća od 2,6 smatra se da je poslovni subjekt stabilan, a ukoliko se nalazi između 2,6 i 1,1 tada pripada „sivoj zoni“. Dakle, ne može se reći da je poslovni subjekt stabilan niti da je pred bankrotom, odnosno predstavlja granično područje između stabilnosti i bankrota. Ukoliko je Z" vrijednost manja od 1,1 tada se predviđa bankrot poslovnog subjekta. Navedeni pokazatelj imao je i dodatak formuli u iznosu $+3,25$ što je omogućavalo usporedbu rezultata modela s rezultatima rangiranja američkih obveznica. Svakako je nužno napomenuti da je riječ o modelu koji je namijenjen predviđanju stečaja za poslovne subjekte koji se nalaze na tržištima koja su u nastajanju, stoga se modelu često puta pripisuje kratica „EM-Score Model“ odnosno „Emerging Market Score Model“ Altman (1995.). Prilagođeni model zapisuje se na sljedeći način:

$$
Z^{\prime \prime \prime}=3,25+6,56 X_{1}+3,26 X_{2}+6,72 X_{3}
$$$$
+1,05 X_{4}
$$

Dobiveni rezultat vrijednosti Z'" score-a iznad 5,85 označava poslovne subjekte kao stabilne, dok „sivu zonu“ predstavlja raspon između 5,85 i 4,35, a područje bankrota rezultat manji od vrijednosti 4,35 .

Jedan od autora koji je obilježio proučavanje problematike predviđanja stečaja poslovnih subjekata je Edward B. Deakin (1972.). On je na uzorku od 64 poslovnih subjekata testirao 14 varijabli za predviđanje stečaja koristeći multivarijatnu diskriminantnu analizu. Autor $u$ radu zaključuje da, iako je prediktivna mogućnost modela na visokih $90 \%$, model bi trebalo koristiti s oprezom.

James Ohlson (1980.) u svome radu koristi logističku regresiju u cilju izbjegavanja problema 
povezanih s multivarijatnom diskriminantnom analizom. Analizirajući 105 poslovnih subjekata koji su doživjeli bankrot i 2058 poslovnih subjekata koji imaju stabilno poslovanje, razvija nekoliko modela s visokim postotkom predviđanja bankrota (>90\%).

Mark E. Zmijewski (1984.) u svome radu formira model za predviđanje bankrota na uzorku od 41 poslovnog subjekta koji su doživjeli bankrot i od 800 poslovnih subjekata sa stabilnim poslovanjem. U modelu uključene varijable mjere uspješnost poslovanja, zaduženost i likvidnost poslovnih subjekata.

Budući da je Altmanov Z-score jednako kao i problematika predviđanja stečaja bila predmetom mnogih drugih istraživanja, osim već navedenih autora, razvoju znanstvene spoznaje u ovom području pridonijeli su sljedeći autori: Edmister, 1972.; Wilcox, 1973.; Altman i McGough, 1974.; Blum, 1974.; Sinkey, 1975.; Libby, 1975.; Argenti, 1976.; Altman i Loris, 1976.; Altman i sur., 1977.; Martin, 1977.; Santomero i Vinso, 1977.; Ketz, 1978.; Pettway i Sinkey, 1980.; Taffler, 1982.; Lawrence i Bear, 1986.; Aziz i sur., 1988.; Koh i Killough, 1990.; Laitinen,1991.; Flagg i sur., 1991.; Baldwin i Glezen, 1992.; Altman i Hotchkiss, 1993.; Rujoub i sur., 1995.; Shumway, 2001.; Hillegeist i sur., 2004.; kao i mnogi drugi.

Pregled istraživačkih radova vezanih uz proučavanje problematike stečaja, pojedinih autora od 1930-tih godina i rezultate do kojih su došli, prikazali su autori Bellovary i sur. (2007.), koji su naveli postojanje 165 studija predviđanja stečaja do 2004. godine, te Aziz i Dar (2006.) koji su temeljem analiziranih rezultata iz 46 članaka u kojima se izvještavalo o 89 empirijskih studija o predviđanju bankrota iznijeli detaljan pregled sažetaka prethodno korištenih istraživačkih metoda i nalaza tih istraživanja.

I u novijim radovima, brojni autori koriste Altmanov Z-score model u kontekstu predviđanja stečaja. Janda i Rakicova (2014.) u svome radu kompariraju bankrote u Češkoj, Srbiji, Slovačkoj i Hrvatskoj s ekonomske i pravne perspektive. Temeljem međunarodnih studija autori zaključuju da je stečajni postupak pretrpio značajne promjene i poboljšao usvajanje novog zakona u sve četiri zemlje, te da je Češka najviše napredovala po pitanju zakona o bankrotu. Altman i sur. (2014.) nastoje istražiti literaturu vezanu uz primjenu Altmanovog Z-score modela na globalnoj razini. Svoj pregled temelje na 33 znanstvena rada koja su objavljena u vodećim financijskim i računovodstvenim časopisima. Autori također testiraju uspješnost originalne verzije Z"-score modela u različitim zemljama koristeći različite statističke metode, te različite varijable. Autori zaključuju da Z"-score model daje izvanredne učinke kada je riječ o međunarodnom kontekstu, te sugeriraju da je moguće postići učinkovitiji model za većinu europskih zemalja koristeći četiri izvorne varijable zajedno s nizom dodatnih varijabli. Prusak (2018.) istražuje procjenu napretka u području istraživanja modela za predviđanje bankrota u zemljama bivšeg istočnog bloka (Poljska, Latvija, Litva, Estonija, Ukrajina, Mađarska, Rusija, Slovačka, Češka, Rumunjska, Bugarska i Bjelorusija) u usporedbi s posljednjim istraživačkim trendovima. Autor zaključuje da su u navedenim zemljama postojali pokušaji razvijanja nacionalnih modela primjenom najjednostavnijih statističkih tehnika i korištenjem isključivo financijskih indikatora kao eksplanatornih varijabli.

Korištenje Altmanovog Z-score modela je u velikoj mjeri zastupljeno u svijetu znanosti ali i izvan njega. Altman (2018.) navodi da se tijekom 50-ak godina od objave Z-score modela pojavio veliki broj aplikacija za praktičare, te je veliki broj i znanstvenih radova koji su koristili Z-score model kao pouzdan i lako primjenjiv alat za predviđanje bankrota poslovnih subjekata, što ukazuje na veliki interes istraživača za navedenu problematiku i aktualnost teme. Osim mnogobrojnih istraživanja provedenih u svijetu i objavljenih radova stranih autora, u Hrvatskoj postoje brojni radovi domaćih autora koji su istraživali i bavili se temama vezanim uz predviđanje bankrota odnosno stečaja. U Tablici 1. se kronološki navode neki od značajnih radova domaćih autora koji su posredno ili neposredno istraživali problematiku stečaja u Hrvatskoj.

Jedan od svakako značajnih domaćih radova u kojem je konstruiran model za ocjenu trenutačne i očekivane poslovne izvrsnosti pod nazivom BEX (eng. Business excellence model) je rad autora Belak i Aljinović Barać (2007.). Navedeni model uključuje četiri pokazatelja s određenim ponderima
Bogdan, S., Bareša, S., Hađina, V.

Testiranje primjenjivosti Altmanovog Z-score modela za predviđanje stečaja u Republici Hrvatskoj 


\begin{tabular}{|c|c|c|}
\hline Autori & Cilj istraživanja & Rezultati \\
\hline Pejić-Bach (1997.) & $\begin{array}{l}\text { Definirati i prikazati način primjene diskriminacijske analize u cilju } \\
\text { predviđanja bankrota poslovnih subjekata. }\end{array}$ & $\begin{array}{l}\text { Istaknute su brojne prednosti u primjeni diskriminacijske analize kao što su: manji utjecaj } \\
\text { subjektivnog suda, bolje razumijevanje problematike, opravdani odabir određene odluke } \\
\text { što rezultira i većim povjerenjem. }\end{array}$ \\
\hline Novak (2003.) & $\begin{array}{l}\text { Ispitati korisnost financijskih pokazatelja za procjenu poslovnih } \\
\text { teškoća banaka u Republici Hrvatskoj na uzorku od } 38 \text { banaka. } \\
\text { U prvoj fazi istraživanja primijenjena je metoda višedimenzio- } \\
\text { nalnih skala (MDS). Cilj je bio utvrditi imaju li banke s poslovnim } \\
\text { teškoćama u odnosu na uspješne banke tendenciju grupiranja u } \\
\text { različitim područjima na karti.U drugoj fazi istraživanja, višestrukom } \\
\text { su diskriminantnom analizom i logit modelom definirane funkcije } \\
\text { klasifikacije dviju skupina banaka, pri čemu su se financijskim } \\
\text { omjerima koristili kao varijablama klasifikacije, da bi se utvrdilo koji } \\
\text { omjeri najviše pridonose klasifikaciji. }\end{array}$ & $\begin{array}{l}\text { Diskriminantna analiza i logit model pokazali su da su varijable (omjeri) profitabilnosti i } \\
\text { likvidnosti najznačajniji za procjenu poslovnih teškoća banaka u Hrvatskoj.Autor jednako } \\
\text { tako argumentira svoje nalaze sličnima nalazima iz drugih zemalja. }\end{array}$ \\
\hline Zenzerović i Peruško (2006.) & $\begin{array}{l}\text { Istaknuti važnost anticipiranja varijabli kojima je moguće predvidjeti } \\
\text { stečaj. Na sveobuhvatan način prezentirane su razne kvantitativne } \\
\text { metode u predviđanju stečaja kao što su: diskriminantna analiza, } \\
\text { modeli linearne vjerojatnosti, logit i probit analiza, višenominalne } \\
\text { logit modeli, stablo odlučivanja i neuronske mreže.Autori od } \\
\text { najznačajnijih ističu modele: Beawera,Altmana, Deakina, Ohlsona, } \\
\text { Edmistera,Zavgrena i Kraliceka. }\end{array}$ & $\begin{array}{l}\text { Prikazani modeli za predviđanje stečaja sastoje se uglavnom od kombinacije financijskih } \\
\text { pokazatelja na kojima se temelje izračuni za predviđanje stečaja. Takvim pokazateljima } \\
\text { nije moguće u potpunosti obuhvatiti kompleksnost poslovanja, stoga autori kao nadopunu } \\
\text { sugeriraju korištenje kvalitativnih varijabli posebice što u tranzicijskim gospodarstvima } \\
\text { kvaliteta financijskog izvještavanja nije dosegla zadovoljavajuću razinu. Autori između } \\
\text { ostalog ističu da prethodno prikazane analize i metode nisu dale zadovoljavajuću osnovu } \\
\text { za daljnja istraživanja. }\end{array}$ \\
\hline
\end{tabular}

Ispitati korisnost financijskih pokazatelja u procjeni poslovnih problema dužnika banke kako bi klasificirali dužnike banke prema razini poslovnih problema. U istraživanju je korišteno 15 omjera

Novak i Crnković (2007.) dobivenih iz financijskih izvješća.U radu je primijenjena višestruka diskriminantna analiza, logit model i metoda višedimenzionalnih skala za razvrstavanje poslovnih subjekata na one koji imaju i na one koji nemaju problema u poslovanju.

Istražiti mogućnosti prognoziranja izloženosti kreditnom riziku, uz istodobno identificiranje raspodjele rizika u bankarskom sektoru i predviđanje vjerojatnosti promjene adekvatnosti kapitala. Cilj je Ivičić i Cerovac (2009.) modeliranje kreditnog rizika nefinancijskih poslovnih subjekata procjenom vjerojatnosti promjene rejtinga i prognoziranjem vjerojatnosti neurednog podmirivanja njihovih obveza u razdoblju od jedne godine, na temelju financijskog računovodstva poduzeća.

Ispitati koliko javno dostupne informacije o bankrotu i financijski izvještaji mogu biti korisni za razvoj modela koji predviđa bankrot.

Pervan, Pervan i Vukoja Studija se temelji na 78 poslovnih subjekata koji su bankrotirali (2011.) i jednako toliko onih koji imaju stabilno poslovanje. U radu je primijenjena diskriminantna analiza i logistička regresija.

Šarlija i Jeger

Izraditi tri modela predviđanja financijskih poteškoća koji će pratiti promjene financijskih omjera poslovnih subjekata tijekom tri (2011.) uzastopne godine. Modeli su razvijeni logističkom regresijom, te se razlikuju prema korištenim financijskim varijablama za svaku godinu.

Testirati sposobnosti predviđanja buduće insolventnosti poslovnih

Pervan i Kuvek subjekata komparirajući model koji uključuje isključivo financijske (2013.) podatke, te model koji uključuje kombinaciju financijskih i nefinancijskih podataka. Autori u radu koriste logističku regresiju.

Keglević Kozjak, Šestanj-Perić i Bešvir (2014.)

Šverko Grdić, Krstinić Nižić i Mamula (2017.)
Testirati u kojoj mjeri korištenje poznatih modela za predviđanje stečaja (Altmanovog Z-score-a, Springate modela, FP rating modela, BEX indexa, Kralicekovog Quicktesta i Bonitesta) može predvidjeti bankrot hrvatskih poslovnih subjekata.

Analizirati financijsku uspješnost poduzeća i predvidjeti njihovu financijsku solventnost koristeći višestruku regresijsku analizu.

Testiraju se dvije hipoteze: (1) Insolventnost hrvatskih kompanija povećala se s globalnom financijskom krizom, te (2) Većina radnji koje je Republika Hrvatska poduzela u smislu zakonodavstva i financijskih poticaja bile su neučinkovite.
Istraživanje je potvrdilo zadanu hipotezu da u financijskim iskazima o poslovanju dužnika banaka postoji određen informacijski sadržaj koji omogućuje da se na osnovi dobivenih modela s visokim stupnjem pouzdanosti razlikuju oni dužnici koji nemaju, od onih koje imaju određenih poslovnih problema. Pokazatelji koje su autori koristili korespodentni su s Altmanovim Z-score modelom.

Model ispravno klasificira $74 \%$ svih poduzeća, $71 \%$ poduzeća koja neuredno podmiruju obveze i 75\% poduzeća koja ih uredno podmiruju.Zaključak je autora da su najvažniji pokazatelji rizika neurednog podmirivanja obveza omjer dioničkog kapitala prema ukupnoj imovini i omjer zarade prije kamata i oporezivanja prema ukupnim obvezama.

Zaključak je autora da kratkoročne obveze, poluga i EBIT mogu biti efektivno korišteni u predviđanju bankrota. Model dobiven diskriminantnom analizom iskazao je 79,5\% točnosti u predviđanju bankrotiranih kompanija, s time da su prilikom izrade modela diskriminantne analize povrijeđene pretpostavke normalnosti podataka i jednakosti kovarijančnih matrica. U odnosu na diskriminantnu analizu model logističke regresije iskazao je veću preciznost u predviđanju u iznosu $85,9 \%$.

Stope predviđanja za sva tri modela u periodu od tri godine kretale su se u rasponu 79,15-84,32\%.Autori iznose zaključak da ukoliko su ekonomski uvjeti stabilni, model može postići adekvatnu preciznost kroz nekoliko godina. Pokazatelji koji su imali manju značajnost u jednoj godini pokazali su se više značajnim u sljedećoj godini. Ukoliko se uvjeti mijenjaju, potrebno je generirati novi model te sugeriraju uključivanje makroekonomskih varijabli.

Nalazi istraživanja sugeriraju da kombinirani model (koji uključuje financijske i nefinancijske podatke) ispravno klasificira 88,1\% poslovnih subjekata dok model koji koristi isključivo financijske parametre na ispravan način klasificira $82,8 \%$ poslovnih subjekata. Empirijski nalaz je pokazao da se predviđanje insolventnosti i upravljanje kreditnih rizikom može poboljšati uključivanjem nefinancijskih podataka.

Temeljem provedenog istraživanja i analizom uzorka od 10 proizvodnih poslovnih subjekata u stečaju, te jednakog broja poslovnih subjekata sa stabilnim poslovanjem kroz vremensko razdoblje 2012.-2013., autori zaključuju da su strani modeli mnogo bolji prediktori u odnosu na domaće modele, pri čemu ističu sljedeće modele s najvećom mogućnošću predviđanja bankrota: Springate model, Bonitest i Z'-score model.

Autori potvrđuju da se insolventnost hrvatskih poduzeća povećala s globalnom financijskom krizom, da hrvatska ekonomija ima problem s rastućom insolventnošću, te su dani prijedlozi na koji način smanjiti nepovoljnu situaciju glede insolventnosti hrvatskih poslovnih subjekata.

Izvor: izrada autora. 
utjecaja koji se odnose na: profitabilnost, likvidnost, stvaranje vrijednosti i snagu financiranja.

Za razliku od svih prethodno navedenih istraživanja koja su se bavila problematikom stečaja u Hrvatskoj, u ovom radu će se ispitati može li Z"-score model predvidjeti neuspjeh poslovnih subjekta sa stupnjem točnosti i pouzdanosti usporedivim s onim koji je Altman dobio u testovima, te da li je moguće konstruirati model $s$ prilagođenim ponderima (pritom zadržavajući jednake varijable) Altmanovog Z"-score modela koristeći se diskriminantnom analizom, koji bi bio primjenjiv, te ujedno uspješniji od njegovog originalnog modela za hrvatsko tržište.

\section{Podaci i metodologija}

lako je Altmanov Z-score model vrlo pouzdan model predviđanja u SAD-u, u cilju ovoga istraživanja testirana je točnost predviđanja Altmanovog modela na poslovnim subjektima iz različitih sektora koji kotiraju ili su kotirali na hrvatskom tržištu kapitala u ukupnom vremenskom razdoblju 2007.-2016. Ukupan istraživački uzorak sastojao se od 52 poslovna subjekta, od čega je 26 subjekata službeno otvorilo stečaj dok se druga polovica uzorka odnosila na poslovne subjekte koji imaju stabilno poslovanje.

S obzirom da su se u uzorku nalazili poslovni subjekti različitih sektora, za izračunavanje Z"- score vrijednosti korištena je formula 3., temeljem koje je moguće testirati poslovne subjekte izvan proizvodnog sektora koji ne kotiraju na burzi. lako su se analizirani poslovni subjekti nalazili na burzi, upravo radi problema s likvidnošću (Bogdan i sur., 2012.) primijenjen je model koji umjesto tržišne vrijednosti kompanije koristi knjigovodstvenu vrijednost. Analiza je izvršena ex-post pristupom budući da se temeljem povijesnih podataka testirao model u cilju dobivanja informacije - da li je stečaj mogao biti predviđen.

Altmanov Z"-score računao se za posljednje tri godine od proglašenja stečaja poslovnog subjekta, te je za usporedbu izračunat i kod poslovnih subjekata koja imaju stabilno poslovanje u istom vremenskom periodu unutar istog ili približno istog sektora. Za izračun Z"-score vrijednosti korišteni su podaci iz financijskih izvještaja (bilanca i račun dobiti ili gubitka) poslovnih subjekta javno dostupnih na službenim stranicama Zagrebačke burze.

$\mathrm{U}$ istraživačkom postupku postavljena su dva zadatka: 1) testirati mogućnost primjene, te ispitati postotak ispravnosti predviđanja Z'-score modela na hrvatskom tržištu, odnosno istražiti da li navedeni model može predvidjeti bankrot poslovnog subjekta u razdoblju od 3 godine prije službenog proglašenja stečaja. Budući da nije riječ

Tablica 2. Pregled sektora prema kojima su razvrstani poslovni subjekti koji su otvorili stečaj

\begin{tabular}{|c|c|c|}
\hline Sektor & $\begin{array}{l}\text { Broj } \\
\text { poslovnih } \\
\text { subjekata }\end{array}$ & Udio u uzorku \\
\hline Poljoprivreda, šumarstvo i ribarstvo & 2 & $7.7 \%$ \\
\hline Proizvodnja prehrambenih proizvoda, pića i duhanskih proizvoda & 3 & $11.5 \%$ \\
\hline Proizvodnja tekstila, odjeće, kože i srodnih proizvoda & 2 & $7.7 \%$ \\
\hline Proizvodnja kemikalija i kemijskih proizvoda & 3 & $11.5 \%$ \\
\hline $\begin{array}{l}\text { Proizvodnja opeke, crijepa i ostalih proizvoda od pečene } \\
\text { gline za građevinarstvo }\end{array}$ & 1 & $3.8 \%$ \\
\hline Proizvodnja osnovnih metala i proizvodnja izrađenih metalnih proizvoda, osim strojeva i opreme & 1 & $3.8 \%$ \\
\hline Proizvodnja transportne opreme & 1 & $3.8 \%$ \\
\hline Ostala prerađivačka industrija, popravak i instaliranje strojeva i opreme & 1 & $3.8 \%$ \\
\hline Opskrba vodom; uklanjanje otpadnih voda, gospodarenje otpadom & 1 & $3.8 \%$ \\
\hline Građevinarstvo & 2 & $7.7 \%$ \\
\hline Trgovina na veliko i na malo; popravak motornih vozila i motocikala & 2 & $7.7 \%$ \\
\hline Prijevoz i skladištenje & 3 & $11.5 \%$ \\
\hline Djelatnosti pružanja smještaja te pripreme i usluživanja hrane & 3 & $11.5 \%$ \\
\hline $\begin{array}{l}\text { Pravne, računovodstvene, upravljačke, arhitektonske djelatnosti i inženjerstvo te tehničko } \\
\text { ispitivanje i analiza }\end{array}$ & 1 & $3.8 \%$ \\
\hline Ukupno & 26 & $100.0 \%$ \\
\hline
\end{tabular}

Izvor: izrada autora. 
Bogdan, S., Bareša, S., Hađina,V.

Testiranje primjenjivosti Altmanovog Z-score modela za predviđanje stečaja u Republici Hrvatskoj
0 istim kalendarskim godinama, uzorak poslovnih subjekata je promatran u ukupnom vremenskom periodu 2007.-2016. godine; te 2) izraditi i testirati uspješnost Altmanovog Z"-score modela s prilagođenim ponderima za hrvatsko tržište.

Uzorak temeljem kojega je provedeno istraživanje razvrstan je po sektorima na način kako je prikazano u Tablici 2.

Slična metodologija ispitivanja mogućnosti primjene Altmanovog modela, te ocjenjivanja njegove uspješnosti primijenjena je i u istraživanjima drugih autora, kao primjerice Alareeni i Branson (2012.), Hussain i sur. (2014.), Celli (2015.), te drugi.

\section{Rezultati i diskusija}

Nakon definiranja istraživačkog uzorka, prikazanog u prethodnom poglavlju, pristupilo se ispitivanju mogućnosti primjene Z"-score modela na hrvatskom tržištu. Najprije je testiran uzorak poslovnih subjekata koji su službeno otvorili stečaj, odnosno subjekti za čije se dionice donijela službena odluka o prestanku uvrštenja na Zagrebačkoj burzi.Postotak uspješnosti predviđanja Z"-score koeficijenata je izračunat na način da se broj ispravno predviđenih poslovnih subjekata u stečaju dijelio s ukupnim brojem poslovnih subjekata koji su službeno otvorili stečaj. Na sličan način izračunata je pogreška tipa I, odnosno broj pogrešno klasificiranih poslovnih subjekata u stečaju $\left(I_{\text {steè }}\right)$ dijelio se je $s$ ukupnim brojem poslovnih subjekata koji su službeno otvorili stečaj $\left(\mathrm{PS}_{\text {stec̀ }}\right.$ ) prema sljedećoj formuli:

$$
\text { Pogreška tipa I = } 1-\frac{I_{\text {steč }}}{P S_{\text {steč }}} \quad 5
$$

Uzorak je analiziran za posljednje tri godine od otvaranja stečaja s time da je godina otvaranja stečaja označena simbolom $T$, te je isti analiziran za prvu (T-1), drugu (T-2) i treću (T-3) godinu prije službenog otvaranja stečajnog postupka. Rezultati analize, prikazani su u Tablici 3.

Kod uzorka poslovnih subjekta koji su otvorili stečaj, jedini je uzrok stečaja bio poslovni neuspjeh, što je vrlo važno napomenuti, jer upravo na tome konceptu Altmanov Z"-score može predvidjeti poslovni neuspjeh. Temeljem dobivenih rezultata (Tablica 3.) zaključuje se da Z"-score model može s vrlo visokom vjerojatnošću predvidjeti stečaj poslovnog subjekta u prvoj godini $(92,3 \%)$, dok je pogreška tipa I izražena sa $7,7 \%$ prilikom testiranja gornje granične vrijednosti, dok je prilikom testiranja donje granične vrijednosti nešto veća pogreška tipa I, te iznosi 11,5\%. U drugoj godini rezultati su identični onima iz prve godine pri čemu se ponovo zaključuje da je model opravdano koristiti. U trećoj godini rezultati su nešto drugačiji, naime prilikom testiranja gornje granice izračunata je manja pogreška tipa I (3,8\%) dok je prilikom testiranja donje granice pogreška tipa I u znatnoj mjeri veća i iznosi 19,2\% temeljem čega se može zaključiti da je veći broj poslovnih subjekata prema izračunatim koeficijentima bio pozicioniran u ,sivoj zoni“.

Nakon testiranja prvog uzorka poslovnih subjekata koji su otvorili stečaj, testiran je drugi uzorak kojeg čine poslovni subjekti koji imaju stabilno poslovanje, i to iz istog ili barem približno istog sektora kao i poslovni subjekti koji su otvorili stečaj. Također su, analogno tomu, promatrane i iste godine kod poslovnih subjekata sa stabilnim poslovanjem. Postotak uspješnosti predviđanja

Tablica 3. Statistika ispravno klasificiranih poslovnih subjekata koji su službeno otvorili stečaj, temeljem testiranja gornje i donje granice Z"-score modela

\begin{tabular}{|c|c|c|c|c|c|}
\hline & $\begin{array}{c}\text { Ispravno } \\
\text { klasificirani } \\
Z^{\prime \prime}<2,6\end{array}$ & $\begin{array}{c}\text { Pogreška } \\
\text { tipa I } \\
z^{\prime \prime}>2,6\end{array}$ & $\begin{array}{c}\text { Ispravno } \\
\text { klasificirani } \\
Z^{\prime \prime}<1,1\end{array}$ & $\begin{array}{c}\text { Pogreška } \\
\text { tipa I } \\
z^{\prime \prime}>1,1\end{array}$ & $\begin{array}{l}\text { Ukupan } \\
\text { uzorak }\end{array}$ \\
\hline \multirow{2}{*}{$\mathrm{T}-1$} & 24 & 2 & 23 & 3 & 26 \\
\hline & $92,3 \%$ & $7,7 \%$ & $88,5 \%$ & $11,5 \%$ & $100,0 \%$ \\
\hline \multirow{2}{*}{$\mathrm{T}-2$} & 24 & 2 & 23 & 3 & 26 \\
\hline & $92,3 \%$ & $7,7 \%$ & $88,5 \%$ & $11,5 \%$ & $100,0 \%$ \\
\hline \multirow{2}{*}{$\mathrm{T}-3$} & 25 & 1 & 21 & 5 & 26 \\
\hline & $96,2 \%$ & $3,8 \%$ & $80,8 \%$ & $19,2 \%$ & $100,0 \%$ \\
\hline
\end{tabular}

Izvor: izrada autora. 
Z"-score koeficijenata je izračunat na način da se broj ispravno ocijenjenih poslovnih subjekata sa stabilnim poslovanjem dijelio s ukupnim brojem takvih subjekata, nakon čega se dobiveni postotak koristio kao stopa ispravno ocijenjenih poslovnih subjekata sa stabilnim poslovanjem. Na sličan način izračunata je i pogreška tipa II, odnosno dijeljenjem pogrešno klasificiranih stabilnih poslovnih subjekata ( $I_{\text {stad }}$ s ukupnim brojem poslovnih

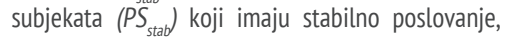
prema sljedećoj formuli:

$$
\begin{array}{|l|l}
\text { Pogreška tipa } I I=1-\frac{I_{\text {stab }}}{P S_{\text {stab }}} & 6
\end{array}
$$

Rezultati analize prikazani su u Tablici 4.

Temeljem dobivenih rezultata prikazanih u Tablici 4. može se zaključiti da su rezultati prilikom testiranja gornje granične vrijednosti $\left(Z^{\prime \prime}>2,6\right)$ nedovoljno pouzdani.Prema izračunatom Altmanovom Z"-score modelu za prvu, drugu i treću godinu, pogreške tipa II iznose $46,2 \%, 50 \%$, te $53,8 \%$. Ukoliko se zaključci izvode prema testiranju donje granične vrijednosti
(Z">1,1) tada su pogreške tipa II znatno manje u odnosu na testiranje gornje granične vrijednosti, te iznose $19,2 \%, 15,4 \%$ i $23,1 \%$ za prvu, drugu i treću godinu. Velike razlike u pogreškama između testiranja gornje i donje granične vrijednosti prisutne su iz razloga što se za prvu godinu u „sivoj zoni“ pozicioniralo 7, za drugu 9, te treću 8 poslovnih subjekata. lako su postotci ispravno klasificiranih poslovnih subjekata koji su službeno otvorili stečaj mnogo pouzdaniji u odnosu na ispravnu klasifikaciju poslovnih subjekata koje karakterizira stabilno poslovanje, svakako je nužno Z"-score model koristiti s oprezom.

Sveukupna ocjena, odnosno postotak ispravnosti predviđanja Z"-score modela na ukupno promatranom uzorku, izračunat je kao postotak ispravno klasificiranih poslovnih subjekata u stečaju i onih koji imaju stabilno poslovanje, što se dijelilo s ukupnim brojem promatranih poslovnih subjekata za svaku godinu. Rezultati testiranja, prikazani su u Tablici 5.

Analizirajući i promatrajući sveukupnu ocjenu primjenjivosti i ispravnosti korištenja Z"score modela na odabranom uzorku poslovnih subjekata u Hrvatskoj, može se zaključiti da je

Tablica 4. Statistika ispravno klasificiranih poslovnih subjekata koji imaju stabilno poslovanje, temeljem testiranja gornje i donje granice Z"-score modela

\begin{tabular}{|c|c|c|c|c|c|}
\hline & $\begin{array}{c}\text { Ispravno } \\
\text { klasificirani } \\
Z^{\prime \prime}<2,6\end{array}$ & $\begin{array}{c}\text { Pogreška } \\
\text { tipa II } \\
\text { Z" }^{\prime \prime}>2,6\end{array}$ & $\begin{array}{c}\text { Ispravno } \\
\text { klasificirani } \\
\text { Z" }^{\prime \prime}<1,1\end{array}$ & $\begin{array}{c}\text { Pogreška } \\
\text { Tipa II } \\
Z^{\prime \prime}>1,1\end{array}$ & $\begin{array}{l}\text { Ukupan } \\
\text { uzorak }\end{array}$ \\
\hline \multirow{2}{*}{$\mathrm{T}-1$} & 14 & 12 & 21 & 5 & 26 \\
\hline & $53,8 \%$ & $46,2 \%$ & $80,8 \%$ & $19,2 \%$ & $100,0 \%$ \\
\hline \multirow{2}{*}{$\mathrm{T}-2$} & 13 & 13 & 22 & 4 & 26 \\
\hline & $50,0 \%$ & $50,0 \%$ & $84,6 \%$ & $15,4 \%$ & $100,0 \%$ \\
\hline \multirow{2}{*}{$\mathrm{T}-3$} & 12 & 14 & 20 & 6 & 26 \\
\hline & $46,2 \%$ & $53,8 \%$ & $76,9 \%$ & $23,1 \%$ & $100,0 \%$ \\
\hline
\end{tabular}

Izvor: izrada autora.

Tablica 5. Statistika ispravno ocijenjenih predviđanja temeljem Z"-score modela za ukupni uzorak

\begin{tabular}{|c|c|c|c|c|c|}
\hline & $\begin{array}{c}\text { Ispravno } \\
\text { klasificirani }\end{array}$ & $\begin{array}{l}\text { Neispravno } \\
\text { klasificirani }\end{array}$ & $\begin{array}{c}\text { Ispravno } \\
\text { klasificirani }\end{array}$ & $\begin{array}{l}\text { Neispravno } \\
\text { klasificirani }\end{array}$ & \multirow{2}{*}{$\begin{array}{l}\text { Ukupan } \\
\text { uzorak }\end{array}$} \\
\hline & \multicolumn{2}{|c|}{ Granična vrijednost 2,6} & \multicolumn{2}{|c|}{ Granična vrijednost 1,1} & \\
\hline \multirow{2}{*}{$\mathrm{T}-1$} & 38 & 14 & 44 & 8 & 52 \\
\hline & $73,08 \%$ & $26,92 \%$ & $84,62 \%$ & $15,38 \%$ & $100,00 \%$ \\
\hline \multirow{2}{*}{$\mathrm{T}-2$} & 37 & 15 & 45 & 7 & 52 \\
\hline & $71,15 \%$ & $28,85 \%$ & $86,54 \%$ & $13,46 \%$ & $100,00 \%$ \\
\hline \multirow{2}{*}{$\mathrm{T}-3$} & 37 & 15 & 41 & 11 & 52 \\
\hline & $71,15 \%$ & $28,85 \%$ & $78,85 \%$ & $21,15 \%$ & $100,00 \%$ \\
\hline
\end{tabular}

Izvor: izrada autora. 
Bogdan, S., Bareša, S., Hađina,V.

Testiranje primjenjivosti Altmanovog Z-score modela za predviđanje stečaja u Republici Hrvatskoj

Tablica 6. Korelacijska matrica

\begin{tabular}{|c|c|c|c|c|}
\hline & $X_{1}$ & $X_{2}$ & $\mathrm{X}_{3}$ & $\mathrm{X}_{4}$ \\
\hline$X$ & 1,000 & 0,847 & 0,454 & 0,199 \\
\hline$X_{2}$ & 0,847 & 1,000 & 0,371 & 0,152 \\
\hline$X_{3}$ & 0,454 & 0,371 & 1,000 & 0,131 \\
\hline$X_{4}$ & 0,199 & 0,152 & 0,131 & 1,000 \\
\hline
\end{tabular}

Izvor: izrada autora.

Tablica 7. Test jednakosti sredina

\begin{tabular}{|c|c|c|c|c|c|}
\hline & Wilks' Lambda & F & df1 & df2 & 0,000 \\
\hline$X_{2}$ & 0,707 & 20,720 & 1 & 50 & 0,000 \\
\hline$X_{3}$ & 0,595 & 34,071 & 1 & 50 & 0,015 \\
\hline$X_{4}$ & 0,887 & 6,356 & 1 & 50 & \\
\hline
\end{tabular}

Izvor: izrada autora.

njegova sposobnost predviđanja relativno visoka. Utvrđivanje ispravnosti predviđanja modela, odnosno testiranje na gornju granicu za prvu, drugu i treću godinu iznosi $73,8 \%, 71,15 \%$ i $71,15 \%$, dok testiranje na donju granicu sugerira nešto veću uspješnost predviđanja za prvu, drugu i treću godinu u iznosu 84,62\%, 86,54\%, 78,85\%. Prema dobivenim rezultatima može se opravdati svrhovitost korištenja Z"-score modela, no svakako je nužno navedeni model koristiti u kombinaciji s drugim modelima za predviđanje stečaja, te je uputno također ne koristiti ga kao osnovni pokazatelj, već kao dodatni.

$U$ drugom dijelu istraživanja nastojati će se prilagoditi Altmanov Z"-score model hrvatskom tržištu, te ce se testirati njegova prediktivna sposobnost. U istraživačkom dijelu koristiti će se jednake varijable koje su korištene i kod Z"score modela samo će se kalibrirati ponderi u modelu primjenom iste metodologije kao i u originalnom radu, odnosno korištenjem višestruke diskriminantne analize.

Prilikom izračunavanja modela višestruke diskriminantne analize korišten je isti uzorak kao i u prethodnoj analizi, odnosno 26 poslovnih subjekata koji su proglasili stečaj i 26 poslovnih subjekata koji imaju stabilno poslovanje. Model je izrađen prema financijskim pokazateljima dobivenim iz financijskih izvještaja godinu dana prije otvaranja službenog stečaja, te je, analogno tomu, ista godina korištena $\mathrm{i}$ kod poslovnih subjekata koji imaju stabilno poslovanje. Budući da će se nastavak istraživanja odnositi na kalibraciju pondera primjenom višestruke diskriminantne analize, u nastavku je prikazana diskriminantna funkcija Zk koja će imati će sljedeći oblik:

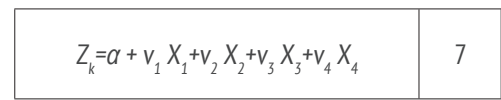

Varijable su definirane na sljedeći način:

$Z_{k}$ Diskriminantna vrijednost

a Konstanta

vi Diskriminantni koeficijent, gdje je i = 1, 2, 3,4

$X_{1}$ Obrtni kapital/ukupna imovina

$\mathrm{X}_{2}$ Zadržana dobit/ukupna imovina

$X_{3}$ Dobit prije kamata i poreza/ukupna imovina

$X_{4} \quad$ Knjigovodstvena vrijednost kompanije/ knjigovodstvena vrijednost ukupnih obveza

Prije izračuna samog modela napravljeno je nekoliko predtestova. Prvi test se odnosio na izračun korelacijskih koeficijenata koji su prikazani u Tablici 6.

Temeljem prikazanih koeficijenata može se naslutiti problem multikolinearnosti zbog visokog koeficijenta korelacije $(0,847)$ između varijabli $X_{1}$ i $X_{2}$, temeljem čega je ispravno ukloniti jednu od navedenih varijabli. Budući da je diskriminantna analiza osjetljiva na multikolinearnost nezavisnih varijabli,u daljnjem istraživačkom postupku uklonit će se varijabla $X_{1}$. Sljedeći najviši koeficijent korelacije, koji se može uočiti, iznosi 0,371 između varijabli $X_{3}$ i $X_{2}$. Budući da nije riječ o visokom 
Tablica 8. Eigenvalues

\begin{tabular}{|c|c|c|c|c|}
\hline Function & Eigenvalue & \% of Variance & Cumulative \% & Canonical Correlation \\
\hline 1 & $0,858^{\mathrm{a}}$ & 100,0 & 100,0 & 0,679 \\
\hline
\end{tabular}

Izvor: izrada autora.

a. U analizi je korištena prva kanonička diskriminativna funkcija

Tablica 9. Wilks' Lambda

\begin{tabular}{|c|c|c|c|c|}
\hline Test of Function(s) & Wilks' Lambda & Chi-square & df & Sig. \\
\hline 1 & 0,538 & 30,039 & 3 & 0,000 \\
\hline
\end{tabular}

Izvor: izrada autora.

koeficijentu, nastavilo se $s$ daljnjim testiranjem modela kojega čine varijable $\mathrm{X}_{2}, \mathrm{X}_{3} \mathrm{i} \mathrm{X}_{4}$.

Također je proveden test jednakosti sredina (Tablica 7.) temeljem čega su postavljene dvije hipoteze:

$\mathrm{H}_{0}$ : Sve sredine su jednake

$H_{1}$ : Najmanje jedna sredina je različita od ostalih

Prema prezentiranim rezultatima u Tablici 7. može se zaključiti da se odbacuje za sve prediktore hipoteza $\mathrm{HO}$, a statistički su značajne $(p<0,05)$ varijable $X_{2}, X_{3}$ i $X_{4}$, nakon čega se pristupilo izračunu kanoničke korelacije. Rezultati kanoničke korelacije i statističke značajnosti modela prikazani su u Tablicama 8.i 9.

Temeljem dobivenog rezultata prikazanog $u$ Tablici 8., s obzirom da postoje samo dvije grupe, procijenjena je jedna diskriminantna funkcija. Svojstvena, odnosno karakteristična vrijednost funkcije iznosi 0,858 i odnosi se na $100 \%$ objašnjene varijance. Budući da je kanonička korelacija 0,679 , može se zaključiti da je $46,10 \%$ varijance zavisne varijable objašnjeno modelom. Prema rezultatima prikazanim u Tablici 9., može se zaključiti da je model statistički značajan $(p<0,05)$. U nastavku je prezentiran diskriminantni model (za novi kalibrirani $Z_{k}$-score model):

\begin{tabular}{|l|l|}
\hline$Z_{k}=0,376+0,586 X_{2}+6,731 X_{3}+0,08 X_{4}$ & 8 \\
\hline
\end{tabular}

U posljednjem istraživačkom postupku procijenjena je uspješnost $Z_{k}$-score modela temeljem dobivenih graničnih vrijednosti -0,908 i 0,908.

Na osnovi dobivenih rezultata prikazanih u Tablici 10. može se zaključiti o nešto većoj uspješnosti klasificiranja poslovnih subjekata u stečaju i onih koji imaju stabilno poslovanje prilikom testiranja gornje granične vrijednosti od 0,908 . Isto tako bitno je napomenuti da predstavljeni rezultati iz Tablice 10. za $Z_{k}$-score model ne nadmašuju rezultate dobivene primjenom originalnog Altmanovog Z"-score modela iz Tablice 5. Prilikom izračuna kalibriranog modela zbog problema multikolinearnosti, korištene su 3 varijable $\left(X_{2} X_{3}\right.$ i $X_{4}$ ) iz originalnog Altmanovog Z"-score modela, dok je varijabla $\left(X_{1}\right)$ obrtni kapital/ukupna imovina izostavljena. Povećanjem broja financijskih varijabli odstupilo bi se od originalnog Z"-score modela, ali bi se testiranjem većeg broja financijskih varijabli, primjenom različitih metodologija i testiranjem

Tablica 10. Statistika ispravno ocijenjenih predviđanja temeljem Zk-score modela za ukupni uzorak

\begin{tabular}{|c|c|c|c|c|c|}
\hline & \multicolumn{2}{|c|}{ Granična vijednost $-0,908$} & \multicolumn{2}{c|}{ Granična vrijednost 0,908} & \multirow{2}{*}{ Ukupan uzorak } \\
\cline { 2 - 5 } & Ispravno klasificirani & $\begin{array}{c}\text { Neispravno } \\
\text { klasificirani }\end{array}$ & Ispravno klasificiani & $\begin{array}{c}\text { Neispravno } \\
\text { klasificirani }\end{array}$ & \\
\hline T-1 & 35 & 17 & 36 & 16 & 52 \\
\hline T-2 & $67,31 \%$ & $32,69 \%$ & $69,23 \%$ & $30,77 \%$ & $100,00 \%$ \\
\hline T-3 & 33 & 19 & 37 & 15 & 52 \\
\hline & $63,46 \%$ & $36,54 \%$ & $71,15 \%$ & $28,85 \%$ & $100,00 \%$ \\
\hline
\end{tabular}

Izvor: izrada autora. 
Bogdan, S., Bareša, S., Hađina,V.

Testiranje primjenjivosti Altmanovog Z-score modela za predviđanje stečaja u Republici Hrvatskoj većeg broja poslovnih subjekata povećala šansa pronalaska modela $s$ uspješnijim mogućnostima klasifikacije poslovnih subjekata od sadašnjih. $\mathrm{Na}$ temelju dobivenih rezultata istraživanja može se zaključiti da se Altmanov Z"-score ne preporučuje koristiti kao osnovni pokazatelj za predviđanje stečaja na hrvatskom tržištu, već kao dopunski. Dobiveni rezultati temeljem originalnog Z"-score modela sugeriraju veću mogućnost predviđanja, dok kalibrirani model $\left(Z_{k}\right.$-score) ima nešto slabije rezultate, ali niti jedan od modela nije preporučljivo koristiti samostalno.

\section{Zaključak}

Problematika stečaja na hrvatskom tržištu smatra se aktualnom, posebice što je u Hrvatskoj od srpnja 2019. godine, ukupan iznos neizvršenih osnova za plaćanje poslovnih subjekata u Hrvatskoj iznosio gotovo 6,2 milijarde kuna (prema posljednjim podacima hrvatske financijske agencije). Jedan od prvih i ujedno najpopularnijih modela za predviđanje stečaja bio je Altmanov Z-score. Navedeni model prvotno je bio konstruiran za industrijske poslovne subjekte u SAD-u, nakon čega model za predviđanje stečaja postaje interesno područje proučavanja brojnih autora u različitim zemljama. U radu su definirani svi postojeći oblici Altmanovovog Z-score modela, nakon čega je testirana i ispitana točnost predviđanja Z"-score modela koji je prilagođen poslovnim subjektima koji ne moraju nužno biti u sektoru proizvodnje, a u svrhu primjenjivosti i provjeravanja pouzdanosti predviđanja stečaja na primjeru poslovnih subjekata iz različitih sektora koji kotiraju ili su kotirali na hrvatskom tržištu kapitala kroz vremensko razdoblje 2007. - 2016. Istraživanje je provedeno na uzorku od 52 poslovnih subjekata, od čega 26 poslovnih subjekata koji su službeno otvorili stečaj, te su izvršteni sa Zagrebačke burze i 26 poslovnih subjekata sa stabilnim poslovanjem. Analiza primjenjivosti Altmanovog Z"-score testirana je za posljednje tri godine od proglašenja stečaja poslovnog subjekta, te je za usporedbu Altmanov Z"-score računat i kod poslovnih subjekata koji imaju stabilno poslovanje $u$ istom vremenskom periodu, izabranih unutar istih ili barem približno istih sektora. Nakon provedene analize, dobiveni su visoki postoci predviđanja, te se može zaključiti da je Altmanov Z"-score model primjenjiv na hrvatskom tržištu. Naime, kod poslovnih subjekata koji su otvorili stečaj postotak uspješnosti predviđanja za godinu dana ranije iznosi $73,08 \%$ i $84,62 \%$ što je testirano na gornju i donju granicu. Rezultati dvije godine prije proglašenja stečaja sugeriraju uspješnost modela od $71,15 \%$ i $86,54 \%$ prilikom testiranja gornje i donje granice, dok su rezultati uspješnosti za treću godinu isti prilikom testiranja gornje granice $71,15 \%$, te nešto slabiji u odnosu na drugu godinu prilikom testiranja donje granice $78,85 \%$. U cilju prilagodbe Altmanovog Z"-score modela hrvatskom tržištu, primjenom višestruke diskriminantne analize nastojali su se prilagoditi ponderi u originalnom Z"-score modelu. Budući da je jedna od važnih pretpostavki višestruke diskriminantne analize odsutnost multikolinearnosti, iz modela je uklonjena varijabla $X_{1}$, dok su zadržane $X_{2}, X_{3}$ i $X_{4}$. Nakon što je utvrđena signifikanost modela, analizirana je njegova uspješnost. Prilikom analize rezultata utvrđeno je da prilagođeni model $\left(Z_{k}\right)$ ima slabiji postotak uspješnosti predviđanja od originalnog Z"-score modela, što bi se moglo opravdati isključivanjem varijable $X_{1}$ (obrtni kapital/ukupna imovina). Temeljem provedenog istraživanja, može se zaključiti da pokušaj prilagodbe postojećeg Altmanovog Z"-score modela hrvatskom tržištu korištenjem jednake metodologije nije pružio bolji rezultat, budući da radi zadovoljavanja osnovnih pretpostavki višestruke diskriminantne analize nisu mogle biti zadržane originalne varijable. Za buduća istraživanja bilo bi korisno ispitati primjenjivost i uspješnost ostalih poznatih modela na hrvatskom tržištu (Beaver, Zmijewski i sl.), te u cilju pronalaženja originalnog modela, uključiti veći broj financijskih varijabli jednako kao i veći broj poslovnih subjekata, te primijeniti nekoliko različitih metodologija u izračunu modela za predviđanje stečaja. Ukoliko se obrati pozornost na dobivene postotke ispravno klasificiranih poslovnih subjekata, svakako se može zaključiti da Z"-score model može biti koristan prilikom analize i ukazivanja na vjerojatnost financijske (ne)stabilnosti, ali ga je preporučljivo koristiti u kombinaciji s ostalim modelima i financijskim pokazateljima kako bi se dobila realna prosudba o financijskom stanju promatranog poslovnog subjekta. Kao ograničenje svakako treba istaknuti činjenicu da je testirani Z"-score model originalno 
konstruiran temeljem poslovnih subjekata na američkom tržištu. Isto tako ne preporuča se korištenje navedenog Altmanovog Z"-score modela kao jedinog ili osnovnog pokazatelja prilikom donošenja poslovnih odluka.

\section{Literatura}

Alareeni, B., Branson, J. (2013) Predicting Listed Companies' Failure in Jordan Using Altman Models: A Case Study. International Journal of Business and Management, 8(1): 113-126.

Altman, E. I.(2018) Applications of distress prediction models: What have we learned after 50 years from the Z-Score models? International Journal of Financial Studies, 6(3): 1-15.

Altman, E. I. (1983) Corporate Financial Distress A Complete Guide to Predicting, Avoiding, and Dealing with Bankruptcy. New York: Wiley Interscience, John Wiley and Sons.

Altman, E. I.(1968) Financial ratios, discriminant analysis and the prediction of corporate bankruptcy. The Journal of Finance, 23(4): 589-609.

Altman, E. I., Danovi, A., Falini, A. (2013) Z-Score Models' application to Italian companies subject to extraordinary administration. Journal of Applied Finance, 23(1): 128-137.

Altman, E. I., Haldeman, R. G., Narayanan, P.(1977) ZETA Analysis: A New Model to Identify Bankruptcy Risk of Corporations. Journal of Banking and Finance, 1(1): 29-54.

Altman, E. I., Hartzell, J., Peck, M. (1995) Emerging Markets Corporate Bonds: A Scoring System. New York: Salomon Brothers.

Altman, E. I., Hotchkiss, E. (1993) Corporate financial distress and bankruptcy. Hoboken, New Jersey: John Wiley \& Sons, Inc.

Altman, E. I., Iwanicz-Drozdowska, M., Laitinen, E. K., Suvas, A. (2014) Distressed firm and bankruptcy prediction in an international context: A review and empirical analysis of Altman's Z-score model. SSRN Electronic Journal. Doi: 10.2139/ssrn.2536340.

Altman, E. I., Loris, B. (1976) A financial early warning system for over-thecounter broker-dealers. The Journal of Finance, 31(4): 1201-1217.

Altman, E. I., McGough, T. P. (1974) Evaluation of a Company as a Going Concern. Journal of Accountancy, (December): 50-57.

Argenti, J. (1976) Corporate Collapse: The Causes and Symptoms. New York: McGraw-Hill.

Aziz, A., Emanuel, D. C., Lawson, G. H. (1988) Bankruptcy prediction - An investigation of cash flow based models. Journal of Management Studies, 25(5): 419-437.

Aziz, M. A., Dar, H. A. (2006) Predicting corporate bankruptcy: Where we stand? Corporate Governance, 6(1): 18-33.

Baldwin, J., Glezen, G.W.(1992) Bankruptcy prediction using quarterly financial statement data. Journal of Accounting, Auditing \& Finance, 7(3): 269-285.

Beaver, W. H. (1966) Financial ratios as predictors of failure. Journal of accounting research, 4: 71-111.

Belak, V.,Aljinović Barać,Ž. (2007) Business excellence (BEX) indeks-za procjenu poslovne izvrsnosti tvrtki na tržištu kapitala u Republici Hrvatskoj. Računovodstvo, revizija i financije, 10: 15-25.

Bellovary, J. L., Giacomino, D. E., Akers, M. D. (2007) A review of bankruptcy prediction studies: 1930 to 
Bogdan, S., Bareša, S., Hađina,V.

Testiranje primjenjivosti Altmanovog Z-score modela za predviđanje stečaja u Republic Hrvatskoj present. Journal of Financial education, 33 (Winter): 1-42.

Blum, M. (1974) Failing company discriminant analysis. Journal of Accounting Research, 12(1): 1-25.

Bogdan, S., Bareša, S., Ivanović, S. (2012) Measuring liquidity on stock market: Impact on liquidity ratio. Tourism and hospitality management, 18(2): 183-193.

Caouette, J. B., Altman, E. I., Narayanan, P., Nimmo, R. (2008) Managing Credit Risk: The Great Challenge for the Global Financial Makets. Hoboken, New Jersey: John Wiley \& Sons, Inc.

Celli, M. (2015) Can Z-Score Model Predict Listed Companies' Failures in Italy? An Empirical Test. International Journal of Business and Management, 10(3): 57-66.

Deakin, E. B. (1972) A discriminant analysis of predictors of business failure. Journal of accounting research, 10(1): 167-179.

Edmister, R. 0. (1972) An empirical test of financial ratio analysis for small business failure prediction. Journal of Financial and Quantitative analysis, 7(2): 1477-1493.

FINA (2019) Informacija o neizvršenim osnovama za plaćanje poslovnih subjekata i građana za srpanj 2019. godine. Dostupno na: https://www.fina.hr/novosti/-/asset_publisher/pXc9EGB2gb7C/content/informacija-o-neizvrsenim-osnovama-za-placanje-poslovnih-subjekata-i-gra-ana-za-srpanj-2019-godine [20.08.2019.].

Fitzpatrick, P. J. (1932) A comparison of ratios of successful industrial enterprises with those of failed firms. Certified Public Accountant (October): 598-605.

Flagg,J.C., Giroux, G.A., Wiggins Jr, C. E. (1991) Predicting corporate bankruptcy using failing firms. Review of financial Economics, 1(1): 67-75.

Hillegeist, S. A., Keating, E. K., Cram, D. P., Lundstedt, K. G. (2004) Assessing the probability of bankruptcy. Review of accounting studies, 9(1): 5-34.

Hussain, F.,Ali, I., Ullah, S.,Ali, M. (2014) Can Altman Z-score Model Predict Business Failures in Pakistan? Evidence from Textile Companies of Pakistan. Journal of Economics and Sustainable development, 5(13): $110-115$.

Ivičić, L., Cerovac, S. (2009) Procjena kreditnog rizika poduzeća u Hrvatskoj. Financijska teorija i praksa, 33(4): 385-413.

Janda, K., Rakicova, A. (2014) Corporate Bankruptcies in Czech Republic, Slovakia, Croatia and Serbia. MPRA Paper 54109, University of Economics, Prague, Charles University in Prague, Prag.

Keglević Kozjak, S., Šestanj-Perić, T., Bešvir, B. (2014) Assessment of Bankruptcy Prediction Models Applicability in Croatia. In: Proceedings of 7th International Conference: An Enterprise Odyssey: Leadership, Innovation and Development for Responsible Economy.Zagreb: Faculty of Economics \& Business Zagreb.

Ketz,J.E. (1978) The effect of general price-level adjustments on the predictive ability of financial ratios. Journal of Accounting Research, 16: 273-284.

Koh, H. C., Killough, L. N. (1990) The use of multiple discriminant analysis in the assessment of the going-concern status of an audit client. Journal of Business Finance \& Accounting, 17(2): 179-192.

Laitinen, E. K. (1991) Financial ratios and different failure processes. Journal of Business Finance \& Accounting, 18(5): 649-673.

Lawrence, E. C., Bear, R. M. (1986) Corporate bankruptcy prediction and the impact of leases. Journal of Business Finance \& Accounting, 13(4): 571-585.

Libby, R. (1975) Accounting ratios and the prediction of failure: Some behavioral evidence. Journal of Accounting Research, 13(1): 150-161.

Martin, D. (1977) Early warning of bank failures: A logit regression approach. Journal of Banking and Finance, 1(3): 249-276. 
Merwin, C. L. (1942) Financing Small Corporations in Five Manufacturing Industries in 1926-1936. New York: National Bureau of Economic Research.

Novak, B. (2003) Predviđanje poslovnih teškoća banaka u Republici Hrvatskoj na osnovi javno dostupnih financijskih pokazatelje. Ekonomski pregled, 54(11-12): 904-924.

Novak, B., Crnković, I. (2007) Klasifikacija dužnika banke prema razini poslovnih problema na osnovi podataka iz osnovnih financijskih izvješća. Ekonomski pregled, 58(1-2): 41-71.

Ohlson, J.A. (1980) Financial ratios and the probabilistic prediction of bankruptcy. Journal of accounting research, 18(1): 109-131.

Ooghe, H., Spaenjers, C., Vandermoere, P. (2009) Business failure prediction: Simple-intuitive models versus statistical models. The IUP Journal of Business Strategy, 6(3-4): 7-44.

Pejić-Bach, M. (1997) Primjena modela diskriminacijske analize i financijskih pokazatelja u prognoziranju bankrota poduzeća. Računovodsvo i financije, 1(11): 515-532.

Pervan, I., Kuvek, T. (2013) The relative importance of financial ratios and nonfinancial variables in predicting of insolvency. Croatian Operational research review, 4(1): 187-197.

Pervan, I., Pervan, M., Vukoja, B. (2011) Prediction of company bankruptcy using statistical techniquesCase of Croatia. Croatian Operational Research Review, 2(1): 158-167.

Pettway, R. H., Sinkey, J. F. (1980) Establishing on-site bank examination priorities: An early-warning system using accounting and market information. Journal of Finance, 35(1): 137-150.

Prusak, B. (2018) Review of research into enterprise bankruptcy pre diction in selected central and eastern European countries. International Journal of Financial Studies, 6(3): 1-28.

Ramser, J. R., Foster, L. O. (1931) A demonstration of ratio analysis. Bureau of Business Research, Bulletin 4, Urbana, University of Illinois.

Rujoub, M. A., Cook, D. M., Hay, L. E. (1995) Using cash flow ratios to predict business failures. Journal of Managerial Issues, 7(1): 75-90.

Santomero, A., Vinso, J. D. (1977) Estimating the probability of failure for commercial banks and the banking system. Journal of Banking and Finance, 1(2): 185-205.

Shumway, T. (2001) Forecasting bankruptcy more accurately: A simple hazard model. The journal of business, 74(1): 101-124.

Sinkey,J. F. (1975) A multivariate statistical analysis of the characteristics of problem banks. The Journal of Finance, 30(1): 21-36.

Šarlija, N., Jeger, M. (2011) Comparing financial distress prediction models before and during recession. Croatian Operational Research Review, 2(1): 133-142.

Šverko Grdić, Z., Krstinić Nižić, M., Mamula, M. (2017) Insolvency in the Republic of Croatia. Ekonomska istraživanja, 30(1): 1693-1704.

Taffler, R.J. (1982) Forecasting company failure in the UK using discriminant analysis and financial ratio data. Journal of the Royal Statistical Society: Series A (General), 145(3): 342-358.

Wall,A. (1936) How to evaluate financial statements. New York: Harper.

Wilcox, J. W. (1973) A prediction of business failure using accounting data. Journal of Accounting Research, 11: 163-179.

Winakor, A. H., Smith R. (1935) Changes in financial structure of unsuccessful industrial companies. Bureau of Business Research, Bulletin 51, Urbana, University of Illinois.

Zenzerović, R., Peruško, T. (2006) Kratki osvrt na modele za predviđanje stečaja. Ekonomska istraživanja, 19(2): 132-151.
Bogdan, S., Bareša, S., Hađina,V.

Testiranje primjenjivosti Altmanovog Z-score modela za predviđanje stečaja u Republici Hrvatskoj 
Bogdan, S., Bareša, S.,

Hađina,, .

Testiranje primjenjivosti

Altmanovog Z-score modela za

predviđanje stečaja u Republici

Hrvatskoj

Zmijewski, M. E. (1984) Methodological issues related to the estimation of financial distress prediction models. Journal of Accounting research, 22: 59-82. 